\title{
Perbandingan Gross Profit Margin PT Mayora Indah dengan PT Nippon Indosari Corpindo
}

\author{
Dian Aryani, Puji Muniarty \\ Program Studi Manajemen \\ Sekolah Tinggi IImu Ekonomi (STIE) Bima \\ Email: puji.stiebima@gmail.com
}

Naskah diterima 24 Maret 2020, Revisi 30 Maret 2020, Terbit 19 April 2020

\begin{abstract}
DOI: doi.org/10.21107/pamator.v13i1.6947

This research was done to study and analyze differences in the gross profit margin of PT. Mayora Indah Tbk with PT. Nippon Indosari Corpindo Tbk. This research uses comparative research. With a sample of research for 10 years from 2009-2018. Samples were taken using purposive sampling technique. The analytical method used is gross profit margin analysis and technical analysis of the data used is the Independent T Test. The results of this study indicate there is no difference between PT. Mayora Indah Tbk with PT. Nippon Indosari Corpindo.
\end{abstract}

Keywords : Gross Profit Margin, Mayora Indah, Nippon Indosari Corpindo

\section{PENDAHULUAN}

Perusahaan merupakan suatu organisasi bisnis yang orientasi utamanya adalah mencari profit atau laba dimana dalam paham ekonomi dikenal istilah "dibutuhkan pengorbanan sekecil-kecilnya untuk memperoleh hasil yang sebesar-besarnya". Untuk menikmati skala ekonomi, perusahaan memaksimalkan penggunaan seluruh sumber daya yang dimilikinya guna mencapai tujuan yang mereka inginkan dan pastinya terdapat dampak kegiatan operasional oleh perusahaan terhadap lingkungan yaitu pencemaran limbah produksi. Sudah menjadi komitmen dan tanggung jawab perusahaan atas dampak yang ditimbulkan baik bersifat social maupun lingkungan di sekelilingnya serta usaha bagi mereka untuk berdaptasi dengan lingkungan sosial masyarakat.

Kinerja keuangan perusahaan sangat ditentukan oleh kualitas kebijakan manajemen yang diambil dalam upaya mencapai tujuan organisasi, sehingga untuk mengukur kinerja keuangan perlu dilaksanakannya analisa laporan keuangan, karena dalam laporan keuangan segala hasil kebijakan manajemen terangkai dan terdokumentasi secara memadai dalam bentuk informasi keuangan. Perusahaan dengan kinerja yang baik mempunyai prospek yang cerah akan profitabilitas perusahaan.
Nilai perusahaan menggambarkan kemampuan perusahaan dalam mengelola sumber daya yang dimiliki, hal tersebut dapat dilihat dari laporan keuangan perusahaan dalam setiap periode, kondisi keuangan yang diharapkan mampu menarik minat investor terhadap perusahaan. Peningkatan nilai perusahaan biasanya ditandai dengan naiknya harga saham di pasar (Rahayu, 2010).

PT Mayora Indah Tbk merupakan perusahaan yang bergerak dibidang industrl pangan. Perusahaan ini berdiri pada tahun 1967 dan pada saat itu masih berupa home industry, hingga sampai tahun 1977 perusahaan ini berubah menjadi badan usaha. PT. Mayora Indah Tbk (MYOR) bergerak dalam bidang pembuatan makanan, permen dan biskuit. Perusahaan menjual produknya baik di pasar domestik maupun luar negeri. perusahaan mulai beroperasi secara komersial.

PT Nippon Indosari Corpindo Tbk berdiri pada tahun 1995. Pabrik pertama berlokasi di Blok W, Kawasan Industri Jababeka, Cikarang. Untuk memenuhi permintaan konsumen yang terus meningkat, Perseroan mengembangkan usahanya dengan mendirikan pabrik di Pasuruan pada tahun 2005. PT Nippon Indosari Carpindo Tbk merupakan salah satu perusahaan roti dengan merek dagang Sari 
Roti terbesar di Indonesia. Perusahaan ini berdiri pada tahun 1995 sebagai sebuah perusahaan penanaman modal asing dengan dengan nama PT Nippon Indosari Corporation. Perkembangan perusahaan ini semakin meningkat dengan semakin meningkatnya permintaan konsumen.

Berdasarkan data penjualan bersih pada PT Mayora Indah Tbk mengalami peningkatan yang signifikan setiap tahun dan berdasarkan data 2009-2018 pendapatan laba kotor juga setiap tahunnya meningkat yang di hasilkan dari penjualan bersih. Hal ini dapat di sebabkan karena tingginya harga jual dan rendahnya harga pokok penjualan.

\section{METODOLOGI}

Dalam penelitian ini peneliti menggunakan jenis penelitian komparatif dengan instrumen penelitian yaitu daftar tabel berupa data laporan keuangan yang terdiri dari atas data Gross Profit Margin. Adapun populasi yang digunakan yaitu laporan keuangan laba rugi atas penjualan bersih dan laba kotor selama 28 tahun dari tahun 1991 sampai dengan tahun 2018. Sampel yang digunakan dalam penelitian ini yaitu laporan keuangan pada PT. Mayora Indah Tbk dan PT. Nippon Indosari Corpindo Tbk mulai dari tahun 2009 sampai 2018 (10 tahun terakhir).

Jenis data yang digunakan yaitu data time series. Teknik pengumpulan data yang digunakan peneliti yaitu studi pustaka dan dokumentasi serta teknik analisa data secara statistik yang digunakan yaitu menggunakan uji independent sample test yaitu untuk mengetahui adakah perbedaan mean atau rerata yang bermakna antara 2 kelompok bebas yang berskala data interval/ rasio dan analisa secara keuangan yaitu menggunakan analisa Gross Profit Margin (GPM). Jika nilai GPM berada pada interval $21 \%-25 \%$ artinya sangat baik; $16 \%-20 \%$ artinya baik, $11 \%-15 \%$ artinya kurang baik dan $>5 \%$ artinya tidak baik (Sawir 2009).

\section{HASIL PEMBAHASAN}

Berdasarkan Gambar 1, menunjukkan bahwa Gross Profit Margin PT Mayora Indah dan PT Nippon Indosari Carpindo sama sama mengalami kondisi yang fluktuatif, dimana peningkatan yang signifikan PT
Mayora Indah pada tahun ditahun 2016 dan 2018 sebesar $27 \%$ berarti perusahaan dapat memaksimalkan keuntungan secara baik. Perolehan hasil yang baik karena hasil dari total pendapatan penjualan seimbang dengan beban penjualan yang harus dibayarkan serta adanya tambahan penghasilan keuangan dan pendapatan lainlain membantu perusahaan dalam mencapai keuntungan yang diinginkan oleh pihak perudahaan. Namun ditahun 2011 dan 2015 Gross Profit Margin PT Mayora Indah mengalami penurunan sebesar $18 \%$ hal ini menunjukkan bahwa perusahaan harus menanggung beban penjualan yang tinggi sehingga menyebabkan rugi sebelum pajak penghasilan tidak maksimal sehingga total keuntungan yang diperoleh kurang memuaskan selain itu karena dipicu dari kerugian selisih kurs.

Kemudian nilai Gross Profit Margin PT Nippon Indosari Corpindo naik drastis di tahun 2015 dan 2018 sebesar $53 \%$ dan $57 \%$. Kinerja keuangan baik karena mendapatkan keuntungan dari hasil penjualan sehingga hasil dari laba sebelum pajaknya bernilai positif. Pada tahun 2016 gross profit margin PT Nippon Indosari Corpindo sempat turun sebesar 52\% karena dalam penggunaan laba kotor terhadap penjualan oleh perusahaan rendah karena berubahnya pola konsumsi masyarat dan rendahnya pertumbuhan industri barang konsumen yang bergerak cepat.

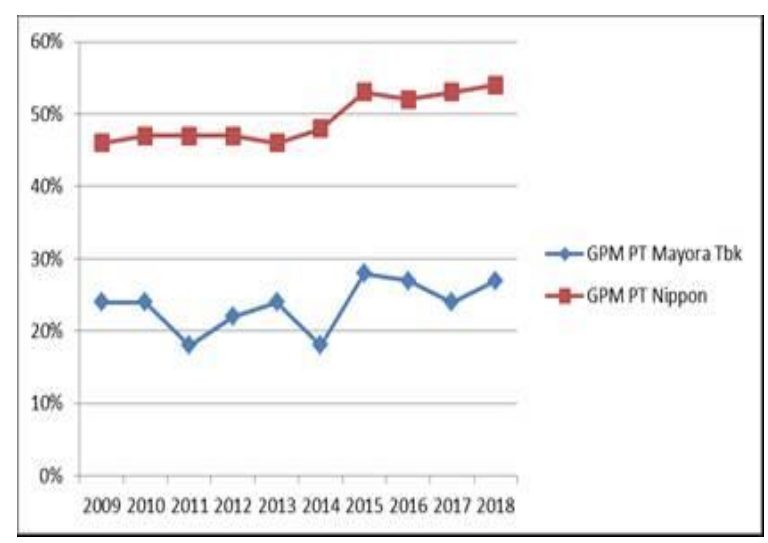

Gambar 1. Nilai Gross Profit Margin (GPM) PT Mayora Indah dan PT Nippo Indosari Corpindo 
Tabel 1. Ouput Pengolahan Uji Independent Sample Test

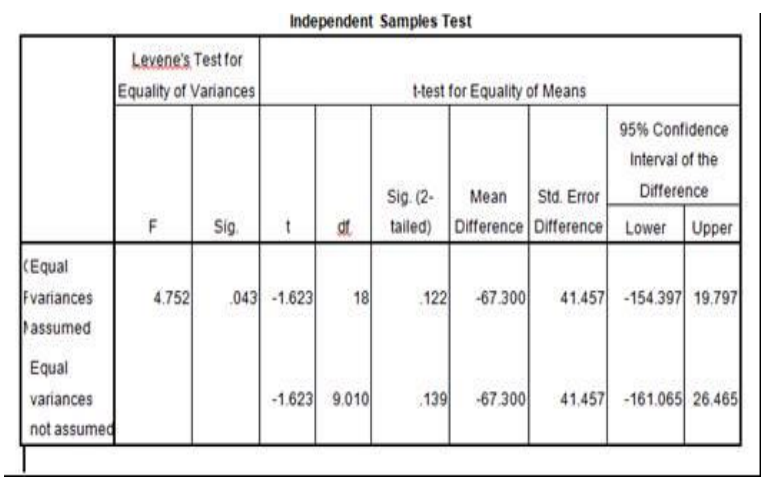

Berdasarkan output diatas diketahui nilai Sig Levene's Test for Equity of Variances adalah sebesar 0,43<0,05 berarti bahwa varians data antara PT. Mayora Indah dengan PT. Nippon Indosari Corpindo tidak sama atau tidak homogen. Berdasarkan tabel output independent sample test pada bagian equel variances assumed diketahui nilai sig (2-tailed) sebesar 0,122>0,05 maka dapat disimpulkan bahwa tidak ada perbedaan yang signifikan (nyata) antara rata-rata Gros Profit Margin antara PT. Mayora Indah dengan PT. Nippon Indosari Corpindo. Untuk nilai $t_{\text {hitung }}$ yaitu sebesar 1,623 sedangkan nilai $t_{\text {tabel }}$ yaitu 2,100 berarti tidak ada perbedaan Gross Profit Margin antara PT. Mayora Indah dengan PT. Nippon Indosari Corpindo.

Berdasarkan hasil uji diatas tidak ada perbedaan Gross Profit Margin antara PT. Mayora Indah dengan PT. Nippon Indosari Corpindo karena secara part time tahunan nilai Gross Profit Margin untuk masingmasing perusahaan mengalami fluktuasi artinya semakin tinggi nilai Gross Profit Margin perusahaan berarti bahwa operasi inti perusahaan dapat dikatakan efisien karena perusahaan mampu menutupi biayabiaya yang ditanggung dengan demikian kegiatan operasional akan berjalan lancar sehingga pendapatan yang diperoleh menjadi besar dan laba perusahaan akan meningkat demikian sebaliknya jika semakin rendah nilai Gross Profit Margin perusahaan berarti operasi inti perusahaan tidak efisien karena harus menanggung biaya-biaya operasional yang berdampak pada minimnya pendapatan dan laba yang akan diperoleh perusahaan.

\section{KESIMPULAN}

Berdasarkan pembahasan yang telah diuraikan di atas, maka diperoleh simpulan bahwa tidak ada perbedaan Gross Profit Margin antara PT. Mayora Indah dengan PT. Nippon Indosari Corpindo. Bagi peneliti selanjutnya disarankan untuk dapat menambahkan variabel-variabel lain yang tidak di cantumkan di dalam penelitian ini. Bagi manajemen perusahaan diharapkan lebih bervariatif dalam mengungkapkan kegiatan-kegiatan yang berhubungan dengan tanggung jawab sosial dalam laporan tahunannya.

\section{DAFTAR PUSTAKA}

Agnes, S. 2009. Analisis Kinerja Keuangan Perencanaan Keuangan Perusahaan. Gramedia Pustaka Utama. Jakarta.

Andarsari, P.R. 2019. The Effect of Firm Size, Gross Profit Margin And Institutional Ownership on Disclosure of Corporate Social Responsibility (CSR). Jurnal Apresiasi Ekonomi. Vol 7. No 3. 301-308 pp.

Fitriani, I. 2010. Perbandingan Return on Equity, Return on Asset, Gross Profit Margin, Net Profit Margin, Operating Profit Margin Sebelum dan Sesudah Akuisisi Perusahaan. Go Public. 1-29 pp.

Hanafi, M.M. 2005. Analisa Laporan Keuangan. Edisi 4. Yogyakarta: UPP AMP YKPN. 
154 Jurnal Pamator 